Journal of Development and Social Change, Vol. 3, No. 1, April 2020

p-ISSN 2614-5766, https://jurnal.uns.ac.id/jodasc

\title{
PERAN AYAH SINGLE PARENT DALAM MENJALANKAN FUNGSI KELUARGA PADA MASYARAKAT MISKIN DI KELURAHAN NUSUKAN KECAMATAN BANJARSARI KOTA SURAKARTA
}

\author{
Tri Dyah Rastiti ${ }^{1}$, LV. Ratna Devi Sakuntalawati ${ }^{2}$ \\ Program Studi Sosiologi Fakultas Ilmu Sosial dan Politik \\ Universitas Sebelas Maret Surakarta Indonesia \\ Email ${ }^{1}$ : tridyahrastiti@gmail.com,Email²: ratnadevi.solo@gmail.com
}

\begin{abstract}
The objective of this thesis research was to describe the role of single parent fathers in carrying out family functions in poor communities in Nusukan Village, Banjarsari Sub-District, Surakarta City. The theory used in this study was the role set theory proposed by Robert K. Merton. This study used a qualitative approach with naturalistic inquiry research method. The sampling technique used was snowball sampling and purposive sampling. The results showed that single parent fathers had carried out family functions. For the socialization function, fathers had become teachers and role models for their children, so that the children had good character. Affection function showed that the fathers became children's playmate, so that the children became more excited and formed self-confidence and independence. In addition, the fathers had given love and affection to their children. The status determination function showed that the fathers had provided support to the children and appreciated their potential. The protection function showed that the fathers had protected and taught discipline to their children. For the economic function, the fathers had fulfilled the needs of children's food, clothing and simple housing. In carrying out family functions, the fathers not only had social relationships with their children, such as the oldest child, neighbors, grandmother, siblings, the father's friends, the school party, and the owner of food stalls and shops.
\end{abstract}

Keywords: Single Parent, Family Function, Poor Society

Abstrak: Tujuan dalam penelitian skripsi ini adalah menggambarkan peran ayah single parent dalam menjalankan fungsi keluarga pada masyarakat miskin di Kelurahan Nusukan Kecamatan Banjarsari Kota Surakarta. Teori yang digunakan dalam penelitian ini yaitu teori perangkat peran (role set theory) yang dikemukakan oleh Robert K. Merton. Penelitian ini menggunakan pendekatan kualitatif dengan metode penelitian naturalistic inquiry. Teknik pengambilan sampel yang digunakan yaitu snowball sampling dan purposive sampling.

Hasil penelitian menunjukkan bahwa ayah single parent sudah menjalankan fungsi keluarga. Pada fungsi sosialisasi, ayah sudah menjadi guru dan teladan bagi anak, sehingga anak memiliki karakter yang baik. Fungsi afeksi menunjukkan bahwa ayah menjadi teman bermain anak, sehingga anak menjadi lebih bersemangat dan membentuk rasa percaya diri dan kemandirian. Selain itu ayah sudah memberikan cinta dan kasih sayang kepada anak. Fungsi 
penentuan status menunjukkan bahwa ayah sudah memberikan dukungan kepada anak dan mengapresiasi potensi yang dimiliki. Fungsi perlindungan menunjukkan bahwa ayah sudah melindungi dan mengajarkan disiplin pada anak. Pada fungsi ekonomis, ayah sudah mencukupi kebutuhan makan anak, pakaian dan tempat tinggal yang sederhana. Ayah dalam menjalankan fungsi keluarga, tidak hanya memiliki hubungan sosial dengan anak, seperti anak tertua, tetangga, nenek, saudara, teman ayah, pihak sekolah dan pemilik warung makan dan toko.

Kata kunci: Single Parent, Fungsi Keluarga, Masyarakat Miskin

\section{PENDAHULUAN}

Pada umumnya didalam kehidupan keluarga, seorang ayah dan ibu memiliki peran sebagai orang tua dari anak-anak. Anggota keluarga saling berhubungan dengan baik, jika tidak maka keluarga tersebut tidak harmonis. Tidak semua keluarga hidup bahagia sesuai yang diharapkan. Tidak sedikit dari pasangan yang hidup berumah tangga menghadapi suatu permasalahan atau persoalan yang tidak ada titik temunya ataupun hal yang lainnya. Disamping itu juga disebabkan karena pasangan hidupnya meninggal. Kematian salah seorang satu dari kedua orang tua merupakan suatu kondisi yang sangat mungkin terjadi pada kehidupan setiap manusia. Hal tersebut merupakan suatu penyebab dimana seseorang terpaksa harus menjalani kehidupan seorang diri.

Tentu saja seorang ayah atau ibu menjadi orang tua tunggal dalam keluarga. Ayah sebagai single parent memang tidak sebanyak ibu sebagai single parent. Jika seorang ayah menjadi single parent, maka harus menjalankan peran ganda dalam keluarga. Menjadi single parent dalam sebuah rumah tangga tentu tidak mudah. Terlebih, bagi seorang suami yang ditinggalkan istrinya, karena meninggal atau bercerai. Dibutuhkan perjuangan berat untuk mengasuh anak, termasuk memenuhi kebutuhan hidup keluarga. Masalah yang sering dihadapi keluarga single parent adalah masalah anak.

Menurut Khaltarina, pada dasarnya anak yang belum siap menghadapi rasa kehilangan akan terpukul, dan kemungkinan besar mengalami perubahan tingkah laku (Listiyanto, 2010). Anak yang hanya memiliki orang tua tunggal cenderung kurang mampu mengerjakan sesuatu dengan baik dibandingkan dengan anak yang berasal dari keluarga yang orang tuanya utuh (Astuti. 2016). Selain itu, seorang anak dapat menjadi pemarah, berkata kasar, suka melamun, agresif, suka memukul, menendang, menyakiti temannya juga tidak berkesempatan untuk belajar perilaku yang baik sebagaimana perilaku keluarga yang harfmonis (Putri, 2016).

Kondisi yang seperti ini akan semakin berat jika anak berasal dari masyarakat miskin. Menurut Liputo (2014) dengan mengalami kemiskinan, maka kesempatan mereka untuk mengakses pendidikan yang baik dan bermutu akan semakin kecil disebabkan ketidakmampuan dalam membiayai sekolah. Disamping itu menurut Delvi (2015) dengan ekonomi keluarga yang memadai seseorang lebih berkesempatan mendapatkan fasilitas belajar yang lebih baik, mulai dari alat tulis hingga pemilihan sekolah dan sebaliknya dengan sosial ekonomi yang kurang memadai seseorang juga kurang mendapatkan fasilitas belajar 
yang baik dan nutrisi yang baik (Delvi, 2015). Tidak hanya itu, biasanya pihak sekolah (pendidikan) tidak memberi keringanan biaya untuk orang miskin atau berpenghasilan rendah (Delvi, 2015).

Anak keluarga miskin lebih berisiko mengalami masalah kesehatan, dan ketika mereka dalam kondisi sakit mereka mengalaminya dalam tingkat yang lebih tinggi dibandingkan anak-anak dari keluarga mampu (Starfield dalam Liputo, 2014). Hal ini disebabkan oleh faktor-faktor yang ada disekitar mereka seperti lingkungan tempat tinggal, nutrisi yang diberikan dan sebagainya. Biaya pelayanan kesehatan akan sulit dijangkau oleh keluarga lapisan bawah, karena mengingat bahwa biaya kesehatan tersebut mahal, sedangkan penghasilan yang didapat rendah.

Disamping itu ayah single parent juga bekerja tetapi mendapatkan penghasilan yang rendah. Penghasilan yang rendah juga membuat keluarga miskin mengalami berbagai macam hambatan untuk memenuhi kebutuhan fisik seperti makanan, pakaian, dan tempat tinggal yang layak (Silalahi dan Meinarno, 2010 : 300). Kenaikan kebutuhan hidup yang semakin tinggi akan menyebabkan ayah yang sebelumnya sulit akan menjadi lebih sulit dalam memenuhi kebutuhan. Sampai saat ini masih banyak ayah single parent yang berasal dari keluarga miskin, khususnya di Kota Surakarta. Berikut data mengenai ayah single parent yang berasal dari masyarakat miskin :

Tabel 1.1 Data Perceraian Laki-laki Masyarakat Miskin Tahun 2018

\begin{tabular}{|l|l|l|l|}
\hline \multirow{2}{*}{ Kecamatan } & \multicolumn{2}{|l|}{ Jenis Perceraian } & \multirow{2}{*}{ Jumlah } \\
\cline { 2 - 3 } & Cerai Hidup & Cerai Mati & 771 \\
\hline Kecamatan Banjarsari & 135 & 636 & 550 \\
\hline Kecamatan Jebres & 104 & 446 & 317 \\
\hline Kecamatan Laweyan & 68 & 249 & 432 \\
\hline Kecamatan Pasar Kliwon & 87 & 345 & 268 \\
\hline Kecamatan Serengan & 61 & 207 & \\
\hline
\end{tabular}

Sumber : Dinas Sosial Kota Surakarta

Berdasarkan tabel tersebut dapat disimpulkan bahwa perceraian hidup atau mati yang dilakukan oleh laki-laki yang berasal dari keluarga lapisan bawah, bahwa setiap kecamatan memiliki jumlah yang berbeda. Pada tahun 2018 perceraian laki-laki terbanyak ada di Kecamatan Banjarsari yang berjumlah 771 kasus dan jumlah kasus percerain terendah ada di Kecamatan Serengan yaitu berjumlah 268 kasus.

Disamping itu seorang ayah single parent harus menjalankan fungsi keluarga. Fungsi keluarga dapat terealisasi apabila hubungan antar anggota keluarga terjalin dengan baik dan maksimal. Jika dilihat dari dari fungsi sosialisasi, pada penelitian Harsanti dan Dwi (2013) mengungkapkan bahwa anak dari keluarga single parent ini telah melakukan perilaku negatif di lingkungan masyarakat, karena disebabkan oleh kondisi rumah yang tidak mendukung. Perilaku negatif tersebut antara lain meminum-minuman keras bersama temannya, selain itu 
juga melalukan perusakan pada fasilitas-fasilitas umum dan mengganggu kenyamanan orang lain. Perilaku anak dari single parent ini tentunya akan mengganggu masyarakat.

Disamping itu dilihat dari fungsi afeksi, penelitian Ayuwanty, Nandang dan Moch (2018) menggambarkan bahwa seorang ayah single parent bersikap dingin dan acuh dengan sesuatu yang berhubungan dengan anaknya, misalnya perkembangan anak disekolah dan kegiatan sehari-hari dirumah. Disamping itu intensitas ayah untuk berinteraksi dengan anaknya hanya sewajarnya. Hal ini akan mengakibatkan anak tidak mendapatkan perhatian dari seorang ayah. Selanjutnya itu jika dilihat dari fungsi perlindungan, penelitian Ayuwanty, Nandang dan Moch (2018) menggambarkan bahwa ayah kurang mengawasi dan mengontrol anaknya sehingga anak memiliki pacar tanpa sepengetahuan ayahnya.

Kemudian fungsi ekonomi, berdasarkan penelitian yang dilalukan oleh Ayuwanty, Nandang dan Moch (2018) mengatakan bahwa seorang anak dengan kondisi ekonomi yang cukup, maka tidak mengalami kesulitan dalam soal biaya dan uang saku, karena anak tersebut berpikir bahwa ayahnya dirasa cukup untuk memenuhi kebutuhan sehari-hari. Jika dilihat dari fungsi penentuan status, peneliyian Harsanti dan Dwi (2013) mengungkapkan bahwa seorang anak tidak patuh dengan orang tuanya. Buktinya anak tersebut meninggalkan rumah dan tidak melanjutkan sekolahnya, karena mereka ingin menikmati suasana yang membuatnya senang. Anak tersebut merasakan kekecewaan yang mendalam dan tidak mampu untuk berdamai dengan keadaan yang ada. Melihat dari isu yang dipaparkan diatas, maka penulis merasa tertarik untuk menggambarkan mengenai peran ayah single parent dalam menjalankan fungsi keluarga pada masyarakat miskin.

\section{METODE PENELITIAN}

Pendekatan yang digunakan yaitu penelitian kualitatif. Lokasi penelitian ini di Kelurahan Nusukan, Kecamatan Banjarsari, Kota Surakarta. Metode penelitian yang digunakan yaitu naturalistic inquiry. Sumber data yang digunakan dalam penelitian ini adalah sumber data primer. Pada penelitian ini, variabel yang digunakan adalah fungsi keluarga. Sedangkan indikator yang digunakan yaitu fungsi sosialisasi, fungsi afeksi, fungsi penentuan status, fungsi perlindungan dan fungsi ekonomis. Populasi yang digunakan yaitu para ayah single parent yang mengalami perceraian mati dan hidup. Disampin itu sample yang digunakan ayah single parent yang mengalami perceraian mati. Teknik pengambilan sample yang digunakan dalam penelitian ini adalah snowball sampling dan purposive sampling. Teknik pengumpulan data yang digunakan yaitu observasi dan wawancara. Teknik Analisis Data yang digunakan yaitu analisis data kualitatif model analisis interaktif (Interactive Model Analisys) yang dikemukakan oleh Miles dan Huberman. Validitas data dengan teknik triangulasi sumber.

Teori yang digunakan dalam penelitian ini adalah Teori Perangkat Peran (role set theory) yang dikemukakan oleh Robert K. Merton. Dapat dikatakan bahwa setiap status bukan hanya memiliki satu peran tapi memiliki beberapa peran. Gambaran struktur sosial ini memunculkan konsep kerangka peran, yang melengkapi hubungan sosial yang bersifat sederhana pada manusia, karena mereka menduduki status sosial khusus (Susilo, 2016 : 205). 
Dapat dikatakan bahwa gambaran dari peran-peran tersebut memunculkan suatu konsep kerangka atau perangkat peran, yang mana melengkapi hubungan sosial pada manusia.

\section{HASIL DAN PEMBAHASAN}

\section{Fungsi Sosialisasi}

Menurut Horton dan Hunt (Pandin, 2016) fungsi sosialisasi yaitu keluarga sebagai pengaruh dan pembentuk kepribadian anak dan sebagai model dalam bersikap dan bertindak. Fungsi sosialisasi dimaknai ayah single parent sebagai teacher and role model. Menurut Hart (Wijanarko dan Ester, 2016 : 139-140) teacher and role model menggambarkan seorang ayah bertangungjawab terhadap apa yang dibutuhkan anak dengan memberikan latihan dan teladan.

a. Mengajarkan latihan pada anak

1. Mengajarkan pekerjaan rumah tangga

Pada hal ini ayah cenderung mengajarkan pekerjaan rumah tangga kepada anak. Dapat diartikan bahwa tidak semua ayah mengajarkan hal tersebut kepada anak. Ayah mengajarkan mencuci baju, mencuci piring dan memasak. Ayah mengajarkan hal tersebut dengan cara mengajarkan cara dan memberikan contoh kepada anak. Selain itu ayah turut serta dalam pekerjaan rumah tersebut kepada anak dan membagi tugas dengan anak-anaknya.

2. Mengajarkan kegiatan diluar rumah Ayah cenderung mengajarkan kegiatan diluar rumah kepada anak. Ayah mengajarkan renang kepada anak. Dalam mengajarkan berenang kepada anak, ayah mengajak anak ke Janti, selain itu juga di Umbul Pelem, dan Pengging. mengajarkan renang kepada anaknya tiga bulan sekali atau hanya saat memiliki waktu longgar saja. Disamping itu ada juga ayah yang mengajarkan musik kepada anak. Saat mengajarkan musik kepada anak, beliau meminjam alat ke tetangga. Beliau mengajarkan musik saat memiliki waktu longgar dan alat yang dipinjam juga sedang tidak digunakan.

b. Mengajarkan teladan kepada anak

1. Mengajarkan cara berbicara

Pada hal ini semua ayah mengajarkan cara berbicara kepada anak. ayah mengajajarkan anak agar tidak boleh berani dengan orangtua dan tidak boleh membentak. Beliau mengajarkan hal tersebut dengan memberikan contoh terlebih dahulu kepada anak. Beliau memberikan contoh dengan tidak boleh membentakbentak ketika berbicara dengan nenek. Selain itu ayah juga mengajarkan anak untuk menggunakan krama alus ketika berbicara dengan orang yang lebih tua.

Beliau mengajarkan dan memberikan contoh untuk mengucapkan matur nuwun ketika di beri sesuatu, mengucapkan nyuwun sewu ketika ada orangtua. Disamping itu ayah juga mengajarkan, jika ada orang yang mencari beliau kemudian anak mengatakan wonten nopo pakde oh bapak nembe tindak, jika diberi sesuatu anak harus mengucapkan matur nuwun, dan ketika ada orang tua anak harus mengucapkan amit nggih pak, bu. 
2. Mengajarkan bersikap

Pada hal ini semua ayah mengajarkan bersikap kepada anak. Ayah mengajarkan sikap adil dan sopan kepada anak. Beliau mengajarkan untuk bersikap adil kepada saudaranya dengan berbagi makanan. Selain itu beliau juga mengajarkan untuk bersikap sopan kepada siapapun seperti dengan tetangga. Selain itu ayah juga mengajarkan untuk saling menghargai antar sesama. Anak harus bergaul dengan siapapun, entah teman itu berasal dari agama yang berbeda, kasta yang berbeda ataupun yang lainnya.

3. Mengajarkan berperilaku

Pada hal ini semua ayah mengajarkan berperilaku kepada anak. pada bagian ini semua ayah mengajarkan anak untuk berbagi makanan dengan saudaranya. Saudara yang dimaksud adalah saudara kandung yaitu kakak atau adik.

\section{Fungsi Afeksi}

Menurut Horton dan Hunt (Pandin, 2016) fungsi afeksi adalah keluarga berfungsi untuk memberikan perhatian dan kasih sayang kepada anggota keluarganya. Fungsi sosialisasi dimaknai ayah single parent sebagai friend and playmate dan caregiver.

\section{Friend and Playmate}

Menurut Hart (Wijanarko dan Ester, 2016 : 139-140) friend and playmate yaitu ayah dianggap sebagai "fun parent" serta memiliki waktu bermain yang lebih banyak dibandingkan dengan ibu. Ayah baik banyak berhubungan dengan anak dalam memberikan stimulasi yang bersifat fisik. Pada bagian ini, peneliti menggunakan konsep yaitu peran ayah dalam bermain dengan anak dan memberi stimulasi bersifat fisik.

a. Bermain dengan anak

Pada hal ini ayah cenderung bermain dengan anak, yang artinya tidak semua ayah menjalankan hal tersebut. Ayah bermain dengan anaknya, dimana beliau menjadi sahabat dan teman bermain bagi anak. Setiap pulang kerja, beliau dan anaknya bercanda-bercandaan. Selain itu beliau juga bermain mobil-mobilan dengan anakanaknya. Disamping itu ayah bermain dengan anaknya, dengan mengajak anak menonton lampion dan cfd, tetapi tidak setiap saat atau dapat dikatakan jarang.

b. Memberi stimulasi bersifat fisik

1. Mengajak anak bepergian

Pada hal ini semua ayah mengajak anak bepergian. Ayah mengajak ke tempat teman beliau saat bepergian dengan anak, itupun hanya sekedar untuk refreshing. Kemudian ayah mengajak anak bepergian ke Tawangmangu, dimana disana merupakan tempat saudara beliau. Jadi beliau mengajak anaknya untuk pergi ke tempat saudara. Selain itu ayah juga mengajak anak untuk jalan-jalan Solo seperti di sekitar Pasar Klewer serta hanya menikmati pemandangan saja. Hal ini dilakukan oleh ayah selama sebulan sekali. 
2. Mengajak anak berekreasi

Semua ayah sudah mengajak berekreasi anak. Ayah mengajak anak berekreasi ke Jurug, Umbul Pelem, pantai, pancingan, Tawangmangu dan Pengging. Beliau mengajak anak berekreasi tiga bulan sekali, tetapi melihat kondisi keuangan dan kebutuhan terlebih dahulu. Kemudian hal ini dilakukan oleh ayah ketika beliau sedang longgar atau tidak ada kegiatan.

\section{Caregiver}

Menurut Hart (Wijanarko dan Ester, 2016 : 139-140) caregiver yaitu ayah dianggap sering memberikan stimulasi afeksi dalam berbagi bentuk, sehingga memberikan rasa nyaman dan penuh kehangatan. Selanjutnya peneliti menggunakan konsep peran ayah single parent dalam melakukan stimulasi afeksi kepada anak.

a. Melakukan stimulasi afeksi

1. Bentuk perhatian kepada anak

Pada hal ini semua ayah memberikan rasa perhatian kepada anak mulai dari fisik, psikis dan pendidikan. Ayah memberikan perhatian fisik anak dengan memperhatikan makanan, jajanan dan minuman yang dikonsumsi oleh anak. Beliau juga memperhatikan psikis anak dengan menemani anak agar tidak merasa kesepian, selain itu beliau tidak mau jika terjadi sesuatu dengan anaknya. Kemudian beliau juga memperhatikan pendidikan, dengan cara bertanya kepada anak setelah pulang sekolah mengenai pelajaran yang telah diberikan oleh guru. Selain itu beliau juga memperhatikan kesehatan anak.

2. Bentuk rasa hormat kepada anak

Semua ayah memberikan rasa hormat kepada anak. Rasa hormat ini ditunjukkan dimana ayah mengharagai pendapat anak. Ayah menghargai pendapat anak jika ingin diantar ke sekolah oleh neneknya. Kemudian juga menghargai pendapat dengan memenuhi keinginan anak. Anak dari beliau ingin bekerja setelah lulus sekolah, tetapi beliau menginginkan jika anaknya kuliah terlebih dahulu. Kemudian beliau menghargai pendapat anak dengan tidak menuntut anak untuk kuliah terlebih dahulu. Selain itu beliau menghargai pendapat anak dalam pemilihan sekolah. beliau menginginkan anaknya untuk bersekolah yang berdekatan dengan rumah, tetapi anak tidak bersedia.

3. Bentuk tanggungjawab kepada anak

Semua ayah memberikan tanggung jawab kepada anak. Tanggung jawab yang dimaksud adalah ayah menyayangi anak dengan tulus. Ayah memiliki cara tersendiri dalam menyayangi anak. Cara yang digunakan yaitu beliau memperhatikan kondisi atau keadaan anak, selain itu juga memperhatikan kebutuhan anak. Selain itu beliau juga membuat senang anak dengan cara beliau sendiri. Selain itu juga dengan memperhatikan kondisi anak. selain itu beliau juga mengajarkan hal-hal yang baik kepada anak seperti mengajarkan cara berbicara, bersikap dan berperilaku. Kemudian ayah juga menyayangi anak dengan tulus dengan cara mengajarkan bersikap dan berperilaku kepada anak. 
4. Bentuk pemahaman kepada anak

Semua ayah memberikan pemahaman kepada anak. Pemahaman yang dimaksud yaitu ayah tidak menuntut anak. Dalam hal ini semua ayah tidak menuntut anak. Ayah tidak menuntut anak, tetapi menginginkan jika anaknya bersekolah sampai pintar. Jika tidak maka akan di slentik. Kemudian beliau tidak menuntut anak, asalkan anak harus patuh terhadap aturan yang diberikan oleh ayah. Selain itu pada saat tes, ayah tidak menuntut anaknya untuk belajar secara terus menerus.

\section{Fungsi Penentuan Status}

Menurut Horton dan Hunt (Pandin, 2016) fungsi penentuan status yaitu yaitu keluarga berfungsi sebagai dasar untuk memberi beberapa status sosial kepada anggota keluarganya. Fungsi penentuan status dimaknai ayah single parent sebagai resource. Menurut Hart (Wijanarko dan Ester, 2016 : 139-140) resource dengan berbagai cara dan bentuk, ayah baik mendukung keberhasilan anak dengan memberikan dukungan di belakang layar.

a. Memberikan dukungan terhadap anak

1. Memberikan bantuan barang untuk mendukung belajar anak

Pada hal ini semua ayah memberikan bantuan barang kepada anaknya. Informan 1 memberikan bantuan barang kepada anak. Beliau memberikan bantuan barang seperti tas, meja belajar dan alat tulis, buku tulis dan sebagainya. Beliau membelikan barang tersebut di daerah Nonongan, agar mendapatkan harga yang murah.

2. Memberikan bantuan jasa untuk mendukung belajar anak

Semua ayah tidak memberikan bantuan jasa kepada anak. Jasa yang dimaksud adalah les privat atau sejenisnya. Ayah tidak memberikan bantuan jasa kepada anaknya karena belum waktunya dan beliau sedang tidak memiliki uang. Selain itu kondisi ekonomi yang belum bisa mencukupi dan kebutuhannya yang lainnya belum tercukupi. Kemudian beliau merasa kasihan kepada anaknya, karena setiap pulang sekolah selalu sore hari, sehingga tidak ada waktu untuk istirahat jika anak les.

3. Fungsi Perlindungan

Menurut Horton dan Hunt (Pandin, 2016) fungsi perlindungan yaitu keluarga berfungsi memberikan perlindungan secara fisik, psikis dan sosial kepada anggota keluarga. Fungsi perlindungan dimaaknai ayah single parent sebagai protector, advocate dan monitor and diciplinarian.

\section{Protector}

Menurut Hart (Wijanarko dan Ester, 2016 : 139-140) protector adalah ayah baik mengontrol dan mengorganisasi lingkungan anak, sehingga anak terbebas dari kesulitan/bahaya. Pada bagian ini, peneliti menggunakan konsep yaitu peran ayah single parent dalam mengontrol lingkungan anak dan mengorganisasi lingkungan anak.

a. Mengontrol lingkungan anak

1. Mengawasi lingkungan pergaulan anak

Semua ayah mengawasi lingkungan pergaulan anak. Ayah mengawasi dengan siapa saja anak berteman, misalnya saja ketika anak berbicara kasar dan mengikuti apa yang 
dikatakan oleh temannya, maka beliau sebagai ayah harus tanggap. Selain itu memberikan nasihat kepada anaknya agar tidak mengulangi lagi. Kemudian juga mengawasi lingkungan pergaulan anak, agar tidak terjerat dalam pergaulan bebas. Selain itu juga mengawasi lingkungan pergaulan anak. Jika anak ingin bermain, maka harus ijin terlebih dahulu terhadap kakak atau tetangganya. Selain itu menasihati anak untuk memilih teman yang baik, agar anak tidak terpengaruh dengan lingkungan yang kurang baik.

b. Mengorganisasi lingkungan anak

1. Mengatur lingkungan pergaulan anak

Pada hal ini ayah cenderung mengatur lingkungan pergaulan anak. Ayah mengatur anak dalam berteman agar tidak terpengaruh oleh lingkungan yang buruk. Selain itu beliau mengatur lingkungan anak, agar anak tidak mengikuti sikap dan perilaku teman-temannya yang buruk. Beliau juga menasihati anak agar tidak berteman dengan orang tersebut. Kemudian Informan 3 juga mengatur lingkungan pergaulan anak. Kemudian juga mengatur pertemanan anak, karena beliau tidak ingin anaknya terpengaruh oleh lingkungan yang buruk.

\section{Advocate}

Menurut Hart (Wijanarko dan Ester, 2016 : 139-140) advocate yaitu ayah baik menjamin kesejahteraan anaknya dalam berbagai bentuk, terutama kebutuhan anak ketika berada di institusi di luar keluarganya. . Pada bagian ini, peneliti menggunakan konsep yaitu peran ayah single parent dalam menjamin kesejahteraan anak.

a. Menjamin kesejahteraan anak

1. Mengembangkan kemampuan sosial anak

Pada hal ini semua ayah sudah mengembangkan kemampuan sosial anak. Ayah memberikan nasihat kepada anak agar dapat bersosialisasi dengan lingkungan sekitar seperti di rumah dan disekolah. Hal ini dilakukan beliau agar anak dapat berteman dengan yang lain, tidak hanya dirumah saja. Beliau mengajarkan anak dengan mengajaknya ke tempat tetangga atau keluar dari rumah, walaupun hanya sekedar bercakap-cakap. Nasihat yang dikemukakan beliau intinya adalah jika tidak bersosialisasi maka tidak akan mempunyai teman.

2. Memberikan perlindungan bagi anak

Semua ayah memberikan perlindungan bagi anak. Ayah memberikan perlindungan anak dengan menasihati untuk tidak terlalu akrab dengan orang yang baru dikenal. Hal ini dilakukan beliau agar anak aman, selain itu jika beliau sedang tidak bersama anak, maka anak akan paham tentang nasihat yang beliau berikan. Selain itu anak juga tidak boleh terlalu percaya dengan orang tersebut. Beliau mengajarkan jika ditanya sesuatu jangan dijawab terlebih dahulu, atau diam saja, kemudian jika diajak ke suatu tempat harus tidak mau.

\section{Monitor and Disciplinarian}


Menurut Hart (Wijanarko dan Ester, 2016 : 139-140) monitor and disciplinarian yaitu ayah baik memenuhi peranan penting dalam pengawasan terhadap anak, terutama begitu ada tanda-tanda awal penyimpangan, sehingga disiplin dapat ditegakkan. Pada bagian ini, peneliti menggunakan konsep yaitu peran ayah single parent dalam pengawasan terhadap anak.

a. Pengawasan terhadap anak

1. Pengawasan terhadap perilaku anak

Semua ayah melakukan pengawasan terhadap perilaku anak. Ayah melakukan pengawasan dengan mengawasi perilaku anak, yang mana jika perilaku anak buruk, maka akan dinasihati ayah. Disamping itu beliau juga memberikan nasihat kepada anaknya untuk tidak berani dengan orangtua. Kemudian beliau juga memperhatikan perilaku anak sewaktu anak melalukannya seperti salim dengan ayah ketika berpamitan. Beliau sudah mengajarkan anak untuk berperilaku yang baik, maka anak harus memiliki perilaku yang sudah diajarkan oleh ayah. Kemudian beliau akan memperhatikan perilaku anak.

2. Menegakkan disiplin

Semua ayah menegakkan disiplin pada anak. Ayah menegakkan disiplin pada anak saat dirumah seperti mengatur waktu saat bangun tidur dan jam tidur siang. Selain itu beliau juga menegakkan disiplin saat di sekolah seperti jika pulang sekolah harus ke rumah dahulu dan mentaati peraturan sekolah. Kemudian beliau juga mengatur jam bermain anak, jika sudah waktunya pulang, maka anak harus segera pulang.

\section{Fungsi Ekonomis}

Menurut Horton dan Hunt (Pandin, 2016) fungsi ekonomis yaitu keluarga berfungsi memberikan pemenuhan kebutuhan ekonomi dan kebutuhan sehari-hari anggota keluarga. Fungsi perlindungan dimaknai ayah single parent sebagai economic provider. Menurut Hart (Wijanarko dan Ester, 2016 : 139-140) economic provider yaitu ayah dianggap sebagai pendukung financial dan perlindungan bagi keluarga. Sekalipun tidak tinggal serumah dengan anak, namun ayah tetap dituntut untuk menjadi pendukung financil. Pada bagian ini, peneliti menggunakan konsep yaitu peran ayah single parent sebagai pendukung financial anak.

a. Pendukung financial anak

1. Kebutuhan pangan

Ayah sudah memenuhi kebutuhan pangan bagi anak. Semua ayah memenuhi kecukupan makan anak. Semua ayah belum memenuhi keamanan, kebergizian, kebermutuan dan keberagaman makan pada anak.

2. Kebutuhan sandang

Semua ayah sudah memenuhi kebutuhan sandang anak. Sandang atau pakaian yang diberikan dapat dikatakan sudah cukup, karena anak dapat menggunakan pakaian yang berbeda-beda untuk kepentingan yang berbeda pula. 


\section{Kebutuhan papan}

Semua ayah sudah memenuhi kebutuhan papan anak walaupun kondisi tempat tinggal yang seadanya dan sederhana. Disamping itu tenpat tinggal yang dihuni masih dapat ditempati.

\section{Pembahasan}

Pada penelitian ini, ayah single parent memiliki status yaitu sebagai ayah. Tentunya beliau memiliki beberapa peran seperti teacher and role model, friend and playmate, caregiver, resource, protector, advocate, monitor and disciplinarian, economic provider. Peran yang dimiliki ayah kemudian diwujudkan dengan fungsi keluarga.

Fungsi sosialisasi diwujudkan dengan peran sebagai teacher and role model. Pada teacher and role model, ayah berperan sebagai guru dan panutan bagi anak. Pada bagian ini, ayah memiliki peran mengajarkan latihan dan teladan kepada anak. Dalam mengajarkan latihan kepada anak, ayah cenderung mengajarkan dan memberikan contoh latihan kepada anak seperti pekerjaan rumah tangga dan kegiatan diluar rumah. Kemudian dalam mengajarkan teladan, menunjukkan bahwa semua ayah mengajarkan dan memberikan contoh teladan kepada anak seperti cara berbicara, bersikap dan berperilaku. Dari hal ini maka tidak semua ayah menjalankan perannya. Kemudian disamping itu menunjukkan bahwa ayah sudah menjadi guru dan penutan bagi anak.

Fungsi afeksi diwujudkan dengan peran sebagai friend and playmate dan caregiver. Pada friend and playmate ayah berperan sebagai sahabat dan teman bermain bagi anak. Pada bagian ini, ayah memiliki peran dalam bermain dengan anak dan memberi stimulasi bersifat fisik. Dalam bermain dengan anak, ayah cenderung menjadi sahabat dan teman bermain saat bermain dengan anak. Kemudian dalam memberi stimulasi bersifat fisik, menunjukkan bahwa semua ayah menjadi sahabat dan teman bermain anak saat memberi stimulasi bersifat fisik kepada anak dengan mengajak bepergian dan berekreasi. Hal ini menunjukkan bahwa ayah sudah menjadi sahabat dan teman bermain anak, tetapi tidak semua ayah menjalankannya. Gambaran dari peran friend and playmate juga masuk ke dalam konsep perangkat peran. Hal ini tentunya juga dilengkapi dengan adanya hubungan sosial antara ayah dan anak, sehingga ayah juga mendapatkan haknya. Setelah itu pada caregiver, ayah berperan sebagai pengasuh anak. Dari hasil penelitian bahwa semua ayah memberikan perhatian, rasa hormat, tanggung jawab dan pemahaan kepada anak.

Fungsi penentuan status diwujudkan dengan peran sebagai resource atau pendukung. Hasil penelitian menunjukkan bahwa semua ayah memberikan dukungan barang kepada anak. Disamping itu semua ayah tidak memberikan dukungan jasa (les) kepada anak. Dapat dikatakan bahwa tidak semua peran dijalankan oleh ayah. Hal ini menunjukkan bahwa ayah sudah menjadi pendukung bagi anak dan peran ini masuk ke dalam konsep perangkat peran.

Fungsi perlindungan diwujudkan dengan peran sebagai protector, advocate, monitor and disciplinarian. Pada protector, ayah berperan sebagai pelindung bagi anak. Dari hasil penelitian menunjukkan bahwa semua ayah mengontrol lingkungan dengan mengawasi lingkungan pergaulan anak. Disamping itu ayah cenderung mengorganisasi lingkungan dengan mengatur lingkungan pergaulan anak. Dapat dikatakan bahwa tidak semua peran 
dijalankan oleh ayah. Hal ini menunjukkan bahwa ayah sudah menjadi pelindung bagi anak dan peran ini juga masuk ke dalam konsep perangkat peran. Pada bagian ini juga dilengkapi hubungan sosial antara ayah dan anak, serta ayah juga mendapatkan haknya. Pada advocate, ayah berperan sebagai penasihat. Hasil penelitian menunjukkan bahwa semua ayah menjamin kesejahteraan anak dengan mengembangkan kemampuan sosial anak dan memberikan perlindungan. Hal ini menunjukkan bahwa ayah sudah menjadi penasihat bagi anak dan peran ini masuk ke dalam konsep perangkat perang. Selain itu juga dilengkapi dengan hubungan sosial antara ayah dan anak, sehingga ayah mendapatkan hak. Monitor and disciplinarian menunjukkan ayah berperan sebagai pemberi disiplin pada anak. Hasil penelitian menunjukkan bahwa semua ayah melakukan pengawasan terhadap anak dengan melakukan pemantauan dan pendisiplinan saat mengawasi perilaku anak serta mendisiplinkan anak.

Fungsi ekonomis diwujudkan dengan peran sebagai economic provider atau pemberi fasilitas ekonomi. Hasil penelitian menunjukkan bahwa semua ayah menjadi pendukung financial anak dengan mencukupi kebutuhan pangan (memberi kecukupan makan), sandang dan papan. Dapat dikatakan bahwa tidak semua peran dijalankan oleh ayah. Kemudian hal ini menunjukkan bahwa semua ayah sudah menjadi pemberi fasilitas ekonomi kepada anak dan tentunya peran ini masuk ke dalam perangkat peran.

Dilihat dari theory of role set yang dikemukakan oleh Robert K. Merton, peneliti mengungkapkan bahwa ayah memiliki status yaitu sebagai ayah. Adanya status tersebut, ayah memiliki beberapa peran. Pada akhirnya peran-peran yang ada sudah dijalankan oleh semua ayah, walaupun ada beberapa bagian yang hanya dijalankan oleh beberapa saja. Gambaran dari peran-peran in, merupakan suatu konsep perangkat peran. Sampai disini dapat dikatakan bahwa beberapa peran ayah merupakan perangkat peran. Adanya perangkat peran ini, maka dapat melengkapi hubungan sosial yang ada. Peran yang dijalankan oleh ayah, melengkapi hubungan sosial yang ada. Hal ini menunjukkan bahwa terdapat hubungan sosial antara ayah dan anak, sehingga ayah mendapatkan hak karena menjalankan perannya.

\section{PENUTUP}

Dalam penelitian ini dapat disimpulkan bahwa ayah single parent menjalankan fungsi keluarga diwujudkan dalam peran-peran. Fungsi sosialisasi diwujudkan dengan peran teacher and role model. Sebagai guru, ayah mengajarkan kegiatan-kegiatan pada sektor publik dan domestik kepada anak. Sebagai panutan, ayah sebagai agen of change bagi anak, dimana ayah merubah anak menjadi lebih baik lagi. Dalam hal ini, ayah menjadi teladan, agar anak dapat mengikuti keteladanan ayah. Jika dilihat dari fungsi sosialisasi, maka ayah sudah mensosialisasikan hal-hal kepada anak, sehingga anak akan belajar dan memiliki karakter yang baik. Pada peran teacher and role model, selain berhubungan dengan anak, ayah juga memiliki hubungan sosial dengan yang lainnya seperti anak tertua, nenek dan tetanga.

Fungsi afeksi diwujudkan dengan peran friend and playmate dan caregiver. Sebagai sahabat, ayah sudah bisa membuat anak menjadi lebih terbuka karena posisi mereka sejajar. Selain itu ayah mampu menciptakan suasana yang menyenangkan dengan mengajak anak ke suatu tempat, sehingga anak menjadi lebih lama dalam bercerita. Sebagai teman bermain, ayah sudah menjadi sosok yang berteman baik dengan anak dan sudah menyempatkan waktu 
untuk bermain dengan anak-anak. Disamping itu saat bermain, ayah membuat anak menjadi lebih bersemangat dan dapat membentuk rasa percaya diri dan kemandirian anak. Pada peran friend and playmate, ayah memiliki hubungan sosial dengan anak tertua, nenek, saudara, teman ayah. Sebagai pengasuh, ayah sudah meluangkan waktunya untuk berinteraksi dengan anak. Pada peran caregiver, ayah memiliki hubungan sosial dengan anak tertua, nenek dan tetangga. Jika dilihat dari fungsi afeksi, maka ayah sudah memberikan rasa cinta dan kasih sayang kepada anak.

Fungsi penentuan status diwujudkan dengan peran resource. Sebagai pendukung, ayah sudah membantu dalam memberikan dukungan kepada anak. Selain itu ayah mengapresiasi potensi yang dimiliki anak. Pada peran resource, ayah memiliki hubungan sosial dengan anak tertua, nenek, tetangga, pihak sekolah. Jika dilihat dari fungsi penentuan status, ayah sudah mendukung anak, sehingga anak mendapatkan status.

Fungsi perlindungan diwujudkan dengan peran protector, advocate, monitor and disciplinarian. Sebagai pelindung, ayah sudah melindungi anak terutama dalam lingkungan pergaulannya. Ayah mengajarkan anak-anak untuk melindungi dirinya sendiri, karena ayah tidak mungkin bersama mereka setiap waktu. Pada peran protector, ayah memiliki hubungan sosial dengan anak tertua, nenek, tetangga dan pihak sekolah. Sebagai penasihat, ayah sudah menyediakan waktu untuk mendengarkan hal yang ingin disampaikan oleh anak serta memberikan masukan kepada anak. Pada peran advocate, ayah memiliki hubungan sosial dengan anak tertua, nenek dan pihak sekolah. Sebagai pemantau, ayah mengawasi perilaku anak baik dirumah maupun di sekolah. Sebagai pendisiplin, ayah menjadi penegak disiplin bagi anak, tetapi disiplin yang dilakukan tetap penuh kelembutan. Pada peran monitor and disciplinarian, ayah memiliki hubungan sosial dengan anak tertua, nenek, tetangga dan pihak sekolah. Jadi dilihat dari fungsi perlindungan, ayah sudah melindungi anak-anaknya.

Fungsi ekonomis diwujudkan dengan peran economic provider. Sebagai pendukung financial anak, ayah sudah memenuhi kebutuhan anak, seperti pangan, sandang dan papan. Ayah memberikan kecukupan makan pada anak, pakain yang sederhana dan tempat tinggal seadanya. Pada peran economic provider, ayah memiliki hubungan sosial dengan anak tertua, nenek, tetangga, pemilik warung makan dan toko. Jika dilihat dari fungsi ekonomis, ayah sudah memenuhi kebutuhan anak.

Dapat diketahui bahwa terdapat hubungan timbal balik antara ayah dan anak, yang kemudian memunculkan konsep perangkat peran. Konsep ini menunjukkan bahwa ayah memiliki beberapa peran. Disamping itu selain berhubungan dengan anak, ayah juga memiliki hubungan sosial dengan yang lainnya. Kemudian dapat diketahui bahwa ayah single parent sudah menjalankan fungsi keluarga. 


\section{DAFTAR PUSTAKA}

Astuti, Denny. 2016. Keterlibatan Pengasuhan Ayah Sebagai Orang Tua Tunggal dengan Anak Perempuannya Setelah Terjadi Perceraian (Studi Kasus Komunikasi Antarpribadi di Desa Kwangsan, Kecamatan Jumapolo).Komuniti, 8(1), 19-34. Ayuwanty, Fitriani., Nandang Mulyana., \& Moch Zainuddin. Prestasi Belajar Anak Dengan Orang Tua Tunggal (Kasus Anak Yang Diasuh Oleh Ayah). Jurnal Pekerjaan Sosial, 1(2), 148-157.

Delvi. 2015. Manajemen Pendidikan Anak di Kalangan Keluarga Miskin. Manajer Pendidikan, 3(2), 115-126.

Harsanti, Intaglia., \& Dwi Gita Verasari. 2013. Kenakalan Pada Remaja Yang Mengalami Perceraian Orang Tua. Proceeding PESAT (Psikologi, Ekonomi, Sastra, Arsitektur \& Teknik Sipil), 5, 71-77.

Liputo, Salahuddin. 2014. Distres Psikologik dan Disfungsi Sosial di Kalangan Masyarakat Miskin Kota Malang. Jurnal Sains dan Praktik Psikologi, 2(3), 286-295.

Listyanto, Budi Dwi. 2010. Agresivitas Remaja yang memiliki Orang Tua Tunggal (Single parent) Wanita. Skripsi. Yogyakarta: Fakultas Psikologi Universitas Gunadarma.

Pandin, Rahmawati Priska. 2016. Fungsi Keluarga Dalam Mendidik Anak Putus Sekolah di Kampung Suaran Kecamatan Sambaliung Kabupaten Berau. eJournal SosiatriSosiologi, 4(3), 71-83.

Silalahi, Karnilawati \& Meinarno Eko A. 2010. Keluarga Indonesia Aspek dan Dinamika Zaman. Jakarta : Rajawali Pers.

Susilo, Rachmad K Dwi. 2016. 20 Tokoh Sosiologi Modern. Jogjakarta : Ar-Ruzz Media. Wijanarko, Jarot \& Ester Setiawati. 2016. Ayah Baik - Ibu Baik Parenting Era Digital Pengaruh Gadget dan Perilaku terhadap Kemampuan Anak. Jakarta : Keluarga Indonesia Bahagia. 